Ewa Starzyńska-Kościuszko (University of Warmia and Mazury)

\title{
RELIGION AND PHILOSOPHY IN AUGUST CIESZKOWSKI'S OUR FATHER
}

\begin{abstract}
This paper presents and discusses the main ideas of August Cieszkowski set forth in his OjczeNasz [Our Father]. This treatise, presently known only to historians of Polish philosophy and historians of ideas, is one of the best examples worldwide of messianic consciousness and approach and, simultaneously, an original attempt to unite philosophy (social philosophy and the dialectical method) with religion. One of the tasks of historians of Polish philosophy is to disseminate the most significant works of older Polish thinkers and make them known internationally. Such then is the aim of this paper. The final sections additionally present contemporary disputes emerging in Poland as to the interpretation of Our Father and my position in these disputes as one of its active participants.
\end{abstract}

Keywords: historiosophy, Cieszkowski, dialectics, philosophy of religion, the Kingdom of God on earth, Polish Romantic messianism.

\section{Introduction}

Our Father, though unfinished, occupies a special place in August Cieszkowski's oeuvre since it represents an attempt to synthesize and summarize philosophical (mainly historiosophical), religious and social ideas presented in his other works. Cieszkowski ${ }^{1}$ himself suggested on many occasions that this is the most important work in his entire oeuvre. During his lifetime, however, he consciously delayed its publication because he was afraid that its religious content would be considered to be heterodoxy discordant with Catholic

- Address for correspondence: Ewa Starzyńska-Kościuszko, Instytut Filozofii, UWM, ul. K. Obitza 1, 10 725 Olsztyn, Poland. Email: ewa.kosciuszko@uwm.edu.pl.

1 August Cieszkowski (1814-1894), an outstanding representative of Polish philosophy of the 1840s, thinker, social activist, economist and messianist. 
teachings of that time. In his moments of despair he actually thought about burning the manuscript. Cieszkowski was aware of the positive and integrating role attributed to the Catholic religion by Polish society ruled by partitioning powers. Thus, before his death he told his son that the time then had not been ripe for the publication of Our Father. Nevertheless, despite his concerns that his work would be received negatively by Polish Catholic circles, and persuaded by Zygmunt Krasiński to do so, he published (anonymously) Wprowadzenie [The Foreword] as the first volume of Our Father in 1848 in Paris. In 1870 one volume edition of the work including The Foreword appeared in Poznań. After Cieszkowski's death, his son, also August, published volume II containing Wezwanie [The Invocation] in 1899, and in 1903 - volume III containing Pierwsza Prośba [The First Petition] and in 1906 - volume IV, in which Druga Prośba [The Second Petition] was included. In the meantime (1905), the third edition of volume one (of 1848) appeared. The complete edition of Our Father, containing all other petitions retraced from Cieszkowski's notes, was published by Adam Żółtowski in Poznań in $1922^{1}$.

The presentation of the content of Our Father should be preceded by comments concerning the ideas that Cieszkowski expounded in his early work written in German, which brought him international renown and recognition, i.e. Prolegomena zur Historiosophie [A Prologue to Historiosophy] (1838). Along with the majority of Polish philosophers of his times, Cieszkowski desired to reconcile philosophy and religion. In the mid- $19^{\text {th }}$ century the relationship of philosophy to religion was heavily influenced by Hegel's and Schelling's philosophical ideas. Hegel's attempt to unite philosophy with religion, however, resulted in the reduction of religion to philosophy. $\mathrm{He}$ elevated and revalued philosophy. Cieszkowski wished to diminish philosophy and strengthen the religious point of view. He began his revision of Hegel's philosophy with historiosophy because he believed it to be the weakest part of the Hegelian system. Cieszkowski rejected a fourfold division of history and adopted a trinitarian division, simultaneously criticizing Hegel for inconsistence in the employment of his own triad dialectical method. According to him, the absence of future was the most significant shortcoming of Hegelian periodization of history. To Cieszkowski's mind, the task of historiosophy is to predict, based on the knowledge of the past, what will happen in the future. Without getting to know future times, without recognizing the future as an integral part of history it is impossible to come to know an organic and ideal totality of [...] history ${ }^{2}$. The totality of history has to contain also the future, which Hegel did not account for in his historiosophy.

Cieszkowski divided history into three periods: past (the era of feeling), present (the era of thought) and future (the era of action). The future may be determined in three ways: through feeling, thought and will. In the first case,

${ }^{1}$ Volumes I and II were published in 1922, but the cover of volume II carries an erroneous date of 1923 when volume III was actually published. The 1922 edition is a three-volume edition. Volume I includes The Foreword, volume II includes The Invocation and The First Petition, volume III contains volume IV of the previous edition and the remaining petitions. This paper is based on the 1922 edition.

${ }^{2}$ A. Cieszkowski, Prolegomena do historyozofii, p. 7. 
this determination is direct, blind, and accidental. It embraces only single facts and creates clairvoyant prophets. The second determination (thought) is of a theoretical and conscious nature. It contains general thoughts and laws and creates philosophers of history. The third one (will) is practical. It embraces the realm of action (theory and practice) and creates the makers of history ${ }^{1}$. Hegel's philosophy concludes the second epoch (the era of thought), but history will be completed in the last epoch (future) and only then will all human desires be fulfilled. Philosophy as such fulfilled itself and achieved its developmental peak in Hegel's philosophy, but this does not signify its end. Philosophy will still develop, however not as theoretical philosophy but as a practical matter. Philosophy must become practical, in other words it must come to life. This transition will occur in the third epoch, that is in the era of action. Hegel elevated the thought and diminished being. His contemplativism and panlogism made it impossible for the philosophy of praxis to develop and for philosophy to come to life, and Cieszkowski criticized this particular aspect of Hegel's philosophy. The development of philosophy, however, does not end with Hegel's ideas. Hegel's philosophy only concludes a certain stage in the development of philosophical thought, but does not end it completely. After Hegel's philosophy a new epoch and a new philosophy (philosophy of action) should come. It will be a direct transition from theoretical issues to practical ones, including economic and social issues. This transition, according to Cieszkowski, as opposed to Hegelian leftist inclinations, will not be of a revolutionary nature but of an evolutionary one.

The inclusion of the future into history understood as the totality of history was not Cieszkowski's original idea. A trinitarian division of history can be found in the works of Joachim de Fiore (Concordia novi ac veteris Testamenti), Schelling (System der transzendentalen Idealismus) and Victor Cousin (Histoire générale de la philosophie). Cieszkowski's correction was, however, significant and was not only of a formal nature. It required a change in Hegel's conception of spirit. According to Cieszkowski, Hegel did not fulfil the condition of the unity of being and thought because in his conception thought is privileged. Thus, philosophy cannot be the ultimate and most supreme expression of the spirit; the spirit's highest power is action and creativity as expressions of the will. In this Polish philosopher's view, the spirit is finally fulfilled not in philosophy, but in history ${ }^{2}$. In his historiosophy Cieszkowski also undermined Hegel's conviction with regards to the significant role of the state in the course of history. Historical missions are fulfilled by nations rather than states. This was a correlative of the absence of Poles (Slavs) in Hegel's historiosophy. Cieszkowski wished to place nations ignored by Hegel within the framework of history.

Cieszkowski, however, remained Hegel's faithful disciple as regards one issue - the dialectical method. Historiosophy presented by Cieszkowski in $A$ Prologue to Historiosophy announces the coming of a new epoch. The Era of

\footnotetext{
${ }^{1}$ A. Cieszkowski, Prolegomena do historyozofii, p. 13.

${ }^{2}$ See M. N. Jakubowski, Ciagłość historii i historia ciagłości, p. 139.
} 
Thought is coming to an end. In his earlier work, Prolegomena do historyozofii [A Prologue to Historiosophy], Cieszkowski expounded historiosophy in a Hegelian manner, in other words philosophically, while at the same time significantly correcting Hegel's ideas through the introduction of the third epoch - the future (the world of action). In Our Father historiosophy is presented in religious terms since it is interpreted as the revelation included in the Lord's Prayer. Cieszkowski attributes the epochs differentiated in his Prologue to the three expressions of the Holy Trinity and his historiosophy takes a millenarian turn. Departure from Hegelian understanding of historiosophy and perceiving it through the prism of religion does not mean, however, that Cieszkowski completely breaks with Hegel and philosophy since he employs Hegel's tools (dialectics). Religious content is expounded with the use of philosophical methods. Historiosophy presented by Cieszkowski in $A$ Prologue to Historiosophy and in Our Father becomes part of the messianic conception according to which the goal of humankind is the Kingdom of God on earth. Cieszkowski reveals the principles of this Kingdom in the seven petitions contained in the Lord's Prayer.

\section{The development of the spirit of mankind}

According to Cieszkowski, though said millions of times, the old Christian prayer Our Father has not been hitherto properly understood. Neither its theological, historical and philosophical meaning has been grasped, nor its relationship to the past, present and future. Most importantly, however, the revelation included in it (extraordinary prophecy) has not been recognized. Thus far men have been repeating it blindly. But this had to be so for the times were not yet fulfilled ${ }^{1}$. Now, according to Cieszkowski, has come the time for the discovery of thoughts hidden in this prayer. Our Father is unique since this prayer is a petition thus it refers to the future, to what has not yet come, but what should be. Cieszkowski, however, was not interested in the prayer as the petition of a single person, but as a social prayer (a universal prayer). He interpreted Our Father in terms of a universal social petition of Christendom rather than as the petition of a single Christian. The Revelation of the future included in Our Father has been hitherto hidden with the word (verbum absconditum) since humankind has not been ready for it. Neither could it be revealed in the Christian Era because this period was wrongly perceived as the final state of humankind while it has only been a transient state, one of preparation. Only in the third epoch will the prophecy be revealed in the form of social action (thought will become action). The requests contained in Our Father may be divided into two classes: positive (affirmative) and negative. Positive are the first five requests of the prayer. Their aim is to make good $a$ certain lack specific for the Christian Era, that is the attainment of such good as this epoch could not be partaker of . Negative are the last two requests of the prayer and they aim at the removal of a certain evil present in the Christian Era.

\footnotetext{
${ }^{1}$ A. Cieszkowski, Ojcze-Nasz, vol. 1, p. 9.

${ }^{2}$ A. Cieszkowski, Ojcze-Nasz, vol. 1, p. 25.
} 
In Cieszkowski's interpretation, the presence of evil in the Christian Era of history does not discredit Christianity as such. Christendom had to contain certain evil. The Revelation of God is a growing process of the education of Humanity, and in this education the presence of evil (passing evils) was an unavoidable and necessary element in the transition into good. These passing evils will themselves retire and pass over into distinct good. This will occur in the third epoch that will begin when the Christian Era is completed.

Cieszkowski, afraid of criticism and accusations of propagating heresy and sacrilegious ideas, frequently emphasized that his aim was not to overthrow Christianity. The thought of the Christian Era of history coming to an end denigrates neither Christianity nor Christ himself. This is not about the dissolution but the completion of Order ${ }^{1}$. When writing about the dissolution of the Christian Era, Cieszkowski did not mean its definitive end and utter annihilation. Contradiction and negation do not equate radical destruction. The end in his understanding means completion or fulfilment. A given epoch comes to an end because it has been completed or fulfilled. A new epoch will witness a radical change and in this sense the previous epoch may be recognized as completed. Transition from one era to another is of an evolutionary nature. It involves creative formation and not destruction. The negation of the previous epoch is not identical with its radical destruction. Cieszkowski strongly opposed revolutionary ideologies as well as revolutionary messianism prophesied at that time by Adam Mickiewicz.

Cieszkowski perceived revolutionaries as heretics, individuals who do not respect history and are reluctant to make any daily effort in order to implement reforms, people who do not believe in the providential course of history. According to him, changes will occur as a result of the evolutionary process. The Kingdom of God on earth will come into being by means of forces already existing and active both in history and religion. Humanity, in Cieszkowski's mind, does not require revolution but evolution. Christianity was a negation of antiquity because the latter epoch had become fulfilled, but this does not mean that the Christian world emerged out of some nihilistic void. What had been valuable in antiquity was absorbed by Christianity, just as what is best in Christendom will be preserved in the next epoch.

The notion of the fulfilment of the second era (Christianity) breeds a vision of the third era, the Era of the Holy Spirit, of the Paraclete, in which what was promised but not fulfilled, will become real. Christ gave humanity all that it needed. If anything is lacking in this gift, it results from not distinguishing between times. Humanity will soon dispel all doubts giving evidence about Christ with actions, not words. Thus mankind will fulfil what it was convened to by him. In order to understand the Lord's Prayer, it is necessary to know the past because it is a preparation for and condition of the future. Consequently Cieszkowski precedes his analysis of Christ's promises contained in the Prayer with a discussion of human history. This is not history understood as a collection of events and ephemeral phenomena. Cieszkowski was concerned

${ }^{1}$ A. Cieszkowski, Ojcze-Nasz, vol. 1, p. 26. 
with the conception of history sub specie ceterni, i.e. with what is essential and spiritually justified, and at the same time eternally important: with what had to be. In other words, history is understood in terms of the most important tendencies, primary principles, main mechanisms of development, i.e. the very progress of the Human Spirit ${ }^{1}$. Thus far, Humanity has passed through two distinct eras. The turning-point and mile-stone of these two epochs was Jesus Christ. The Ancient or Pre-Christian World and the Christian Era, perceived through the prism of ideas characteristic for each of them, are two opposing epochs for Cieszkowski. He interprets this opposition dialectically as the relationship between position and negation, thesis and antithesis, Being and Thought. History thus far, containing all one-sided and opposing positions, was an introductory state that prepared, according to the principles of dialectics, its own synthesis.

This synthesis will be realized in the third epoch which is the effect and goal of all hitherto history. This epoch will be the time of fulfilment of what was only assumed and desired in previous epochs. The third epoch will be the Age of Action, that is complete fulfilment, the epoch of the lordship of humanity over the forces of spirit. The common ruling over these forces aims to establish in them order as well as living and active peace. Action is the embodiment of thought. In Action what should be comes into being. Action embodies thought by implementing it into Being. Action makes Being alive. Only in Action are all human desires completed. It is then the foundation of all existence and life; Action is the proper saviour of mankind that from the seen earth and the ideal paradise will create one: the earthly Paradise ${ }^{2}$. Through work, action and the free work of the Spirit, humankind itself will fulfil its desire of paradise. It is impossible to find the Promised Land; it is to become so through us. Action is not identical with revolution, either political or social. Revolution means destruction; it is both a physical and moral vandalism. We loath deeply all ruination, Cieszkowski writes ${ }^{3}$.

The new epoch will be initiated by Slavic nations since other nations have already fulfilled their historical missions. Now is the time for Slavs to fulfil their mission that has been set forth by God. Slavic nations should lead humanity in this new epoch because of their customs, proclivities and virtues (the love of freedom, honour, peaceful nature, expediency, ability to forgive, lenience in punishment, hospitality, and tolerance), their sufferings and hitherto merits. The Revelation of Christ contains everything that Humanity as humanity should know and fulfil. Cieszkowski stresses that he does not proclaim any new Revelation. This Revelation has existed for a long time but has not been understood and thus has not been realized. When analyzing requests contained in the Lord's Prayer, he uncovers revelations that concern the new state of humanity just approaching. This state has been for the present world the worldto-be, but becomes a new world to us, the final state of humanity, the fulfilment

\footnotetext{
${ }^{1}$ A. Cieszkowski, Ojcze-Nasz, vol. 1, p. 31.

${ }^{2}$ A. Cieszkowski, Ojcze-Nasz, vol. 1, p. 143.

${ }^{3}$ A. Cieszkowski, Ojcze-Nasz, vol. 1, p. 168.
} 
of its historical development, the Kingdom of God on earth. The analysis of requests contained in the Lord's Prayer sets out to explain how this Kingdom of God will be realized on earth.

\section{First petition}

The first request, Hallowed be Thy Name, concerns God himself. This petition, whose subject is God, had to be the first since it is the highest one: There is nothing without God - all things are with Him, and for Him, and through $\mathrm{Him}^{1}$. Without God and religion, sooner or later the world (humanity) is at risk of disintegration and will fall. The unrest and evil of the modern world are due to its rejection of religion and the rending asunder of the religious bond - the only bond able to maintain the unity of the world. Without coherence guaranteed by religion the renewal of the world is impossible.

What does the first petition mean in this context? Cieszkowski mentions interpretative difficulties connected with this message. He deems all the previous attempts to explain this request by Tertullian, Saint Augustine, Thomas Aquinas as overtly intellectual. In order to grasp the meaning of this petition we cannot avail ourselves of any intermediate reflections and create additional theoretical constructions. We must follow the text literally and its literal meaning. The method involved is the natural analysis. This is the only, according to Cieszkowski, way of revealing the truth contained in this petition. This petition, understood directly, mentions two things: the Divine Name and the hallowing thereof. God is always the same, eternal, absolutely unchanging God, but His name has changed because the consciousness of His followers has changed and deepened. The first mention of God employs the word Elohim (Deity). Elohim was not yet a proper name for God and His definition, but only a general term for the Highest Being ${ }^{2}$. It was not yet what the designation of God is to us; it was the foundation to develop His names. The highest expression for God, giving us His substance, is Absolute Being (Jehovah). This is the most perfect name for the Absolute Being, but not its ultimate name. Another name is Christian Logos. Only in Christianity, through Jesus of Nazareth, is the second, ideal face of God revealed: Logos (the Word), that from the idea became the Flesh ${ }^{3}$. Logos is the opposition, the antithesis of the Absolute Being. It is the internal principle of Subjectivity that revealed itself to complement the external principle of objective substance. These oppositions, according to the principles of dialectics, are not mutually exclusive, but complement each other. One becomes the other because they are only part of one eternal identity. In the development of Hebrew thinking, Jehovah becomes the purely ideal first principle of thought (an abstract infinite Spirit), whereas Logos - as the ideal first principle of thought - becomes a real (sensual) phenomenon embodied in a certain man. A dialectical progress of the Divine name is neither an a priori speculation, nor a manifestation of thinking typical of Sophists, but a natural

\footnotetext{
${ }^{1}$ A. Cieszkowski, Ojcze-Nasz, vol. 2, p. 168.

${ }^{2}$ A. Cieszkowski, Ojcze-Nasz, vol. 2, p. 315.

${ }^{3}$ A. Cieszkowski, Ojcze-Nasz, vol. 2, p. 322.
} 
analysis of revelations. The Absolute Being became alive and generally personified in Jehovah (God the Father), in Logos - it became alive and particularized in the idea of God the Son and passed into a real personality in Jesus Christ. God the Father and God the Son are two significant moments of God in the dialectics of Religion - real manifestations of Him. Because human consciousness has already passed through these two dialectical stages, these one-sided views (dialectical moments) do not suffice to satisfy our consciousness of God. God thus far has revealed its one-sided manifestations. The times of approximate notions of God are coming to an end. Consciousness continues to develop towards the synthesis that will reveal Him in our consciousness in the way He wanted to reveal Himself to humankind - In Spirit and in Truth. Today, rather than an approximate one, Christ reveals to humanity His true name: Spirit. An analogous result to that of Revelation is attained by human reason (consciousness). Living, conscious, active Spirit is the synthesis of Being and Thought, of Nature and Idea. God is the absolute Spirit and this is the ultimate definition of God. There can be no further (higher) definition because this one embraces the Whole.

When referring to the notion of Spirit, Cieszkowski rejects the hitherto ways of understanding it, characteristic of the idealistic tradition. Spirit, according to him, is not a negation of matter, a pure conception, an idea itself, something purely abstract without senses. Spirit as conceived of by idealists is both a fancy and chimera. For Cieszkowski, there is no Spirit without matter any more than without thought. Spirit is a living oneness of Spirit and matter, a creature of senses and reason. Once we know the absolute Divine name, it must be explained what it means for God's name to be hallowed. Spirit, the Absolute Spirit in Cieszkowski's terminology to distinguish it from other spirits which are confined and conditioned, is also the Holy Spirit. Holiness is the actual meaning of spirit, its nature, its being and its goal: Spirit exists to be hallowed. It must be hallowed. The Absolute Spirit as such is holy; it is the Holy Spirit. ${ }^{1}$ A similar understanding of holiness can be found in the works of Tertullian and Saint Augustine. A similar does not mean identical, however. In Saint Augustine we find only an hidden petition to recognize God as the Holy Spirit. Cieszkowski reveals this petition explicitly and proclaims it. The meaning of the request Hallowed be Thy Name should be then expressed simply: Hallowed be the Spirit - let mankind come to acknowledge God - the Holy Spirit! Let the Lordship of the Holy Spirit come. ${ }^{2}$ Cieszkowski demands worship for God as Spirit: God is acknowledged by its highest name and demands hallowing this name. This petition is then a prophecy of the new revelation, that of the Third Name of God, the Third Face of God, the Third manifestation - the Revelation of the Holy Spirit ${ }^{3}$. The Revelation of God opens the Third Era of mankind. It begins the third covenant of God and humankind. A detailed analysis of the first

\footnotetext{
${ }^{1}$ A. Cieszkowski, Ojcze-Nasz, vol. 2, p. 341.

${ }^{2}$ A. Cieszkowski, Ojcze-Nasz, vol. 2, p. 342.

${ }^{3}$ A. Cieszkowski, Ojcze-Nasz, vol. 2, p. 342.
} 
request has led Cieszkowski to the assertion that its meaning is the worship of the Holy Spirit.

\section{Second petition}

The object of the second petition is the Kingdom of God promised by Jesus, but not yet fulfilled: Thy Kingdom Come. The first petition concerned God as the highest Goal, the second petition concerns humanity, social relations and all human goods. This petition, according to Cieszkowski, has not been fulfilled in the Christian Era and is not being realized in present times because the hitherto condition of human relations characterized by disorder, chaos and injustice is not suited to the notion of the Kingdom of God. The petition Thy Kingdom Come is in opposition to Christ's words: My Kingdom is not of this world. Christ promised the coming of the Kingdom of God on earth - the belief that this coming will take place is a foundation of Orthodox Christianity - and at the same time he claimed My Kingdom is not of this world. Cieszkowski considers whether this petition is a bitter irony and mystification ${ }^{1}$. Dialectics comes to be helpful in solving this contradiction. If none of these statements can be discarded (both have been said), then, according to Cieszkowski, they must be united. Old prophets had a premonition of the Kingdom of God. This was, however, only sensibly foreseen. In the Christian Era this premonition attained a higher level, i.e. it was conceived of ideally, since that epoch was concerned with the separation of humanity from the world of senses and the external world. This separation was necessary to develop and strengthen the internal and spiritual world. In the Christian Era, the Kingdom of God could not be of this world for that world had to deny itself in order to be born again. It had to transform itself from the world of the senses to the internal world of the reason. The Kingdom of God potentially set up by Christ and then by Apostles and Evangelists will finally be fulfilled, that is it will eventually come. There is thus no contradiction between the petition and Christ's words My Kingdom is not of this world. The Christian revelation brought only the promise of the Kingdom of God, leaving to the Third Age the development of those elements, hitherto only ideas, and the fulfilment of the Third Revelation. This Kingdom actually exists in a different world (in Heaven), but this does not mean that it cannot exist as Paradise on earth. The Kingdom of God has been thus far not of this world because it could not be of it. It was, however, conceived to be for our world. And it will become of this world when our world matures and becomes normal.

\section{Third petition}

The next petition, Thy will be done in earth, as it is in heaven, concerns liberty. Anticipating potential accusations that this request does not refer to liberty (our liberty), but to the necessity of submitting to the will of God, Cieszkowski asserted that liberty does not mean that we do not submit to the will of God. His analysis of this request seeks to prove that there is no difference

\footnotetext{
${ }^{1}$ A. Cieszkowski, Ojcze-Nasz, vol. 3, p. 3.
} 
between fulfilling the will of God and fulfilling our will, that they are both the same in Heaven and on earth. Liberty is an immanent and highest attribute of the Spirit. This does not mean that it excludes its other designations. If it were so, the Spirit would remain an abstraction. In fact, the Spirit is not abstract but concrete. Liberty is preceded by Love and Wisdom. Cieszkowski interprets thinking (wisdom) along Cartesian lines since cogito ergo sum expresses truth that cannot be overthrown. It can be, however, transgressed and intensified because a person may be thinking but not willing. Hence the formula volo, ergo sum et cogito. If [t]hinking implies Being, then will implies in itself Being and Thinking ${ }^{1}$. Will, according to Cieszkowski, is the highest attribute of the Spirit, the Sum of the Spirit because it unites Thought and Sense. Particular states of the Spirit are fully spiritual when they are free. Liberty is the highest state. The highest state of the Sense is love. What we love out of will is the highest product of spiritual life. Through will we worship what is contained in the Spirit of Humanity; will is the fulfilment of the Spirit ${ }^{2}$. In the dispute concerning determinism and indeterminism Cieszkowski supported neither of these standpoints since both, according to him, proclaim correct and incorrect judgments at the same time. Will is submitted to external (senses - feelings) and internal (thought - reason) determinants. It depends, on the one hand, on senses and reason, but, on the other hand, can do whatever it wishes with these determinants (accept, reject, change). In this sense will has liberty, and it is actually wilful and selfwilled, and definitely autonomous. Each act of will contains in itself both liberty and necessity. Liberty is, however, not only being, but it also develops itself and is action out of itself. Only when it develops in itself, does it cease to reveal itself as contradictory states; moreover, it then harmonizes these states and becomes a real and actual liberty ${ }^{3}$. Neither the Human Spirit nor the Spirit of Humanity has attained such liberty thus far. It has approached it, but not fulfilled it. In the Ancient Era man understood will as contradictory to his own will Fatum; in the Christian Era man decided that God demanded of him independence. The awakening of will, characteristic for Christianity, will be a higher level of liberty, but not yet the real liberty, only a general precept. Humanity has possessed hitherto only an ersatz of liberty. Liberty will become real when the Holy Spirit becomes active in Humanity.

\section{Fourth petition}

Out of all requests contained in the Lord's Prayer, the fourth petition, Give us this day our daily (epiousios) bread, is most controversial. This request concerns the material world while Christianity was meant to be its antithesis. Christian commentators on this petition, sensing the contradiction contained in it, attempted to interpret it metaphorically and ascetically, that is in accordance with the spirit of their faith. Cieszkowski disagreed with such interpretations mostly because all petitions, including this one, refer to the future and not to the

\footnotetext{
${ }^{1}$ A. Cieszkowski, Ojcze-Nasz, vol. 3, p. 157.

${ }^{2}$ A. Cieszkowski, Ojcze-Nasz, vol. 3, p. 160.

${ }^{3}$ See A. Cieszkowski, Ojcze-Nasz, vol. 3, pp. 163-164.
} 
present. This is evidenced by the present situation of the lower social classes. Feudal law, fiscalism, exploitation and oppression on the part of all social institutions are the source of poverty and destitution. The totality of this exploitation creates an impression of ripping out from humanity the goods necessary to live. Attempts to change and improve this state of affairs (philanthropy) are, according to Cieszkowski, ineffective. These attempts do not give people the means with which they might attain dignity necessary to become a member of society and a citizen. Moreover, they also deprive people of the abstract dignity ascribed to them by Christianity. The present that deprives humankind of daily bread is not able to fulfil this dignity, and the undertaken remedies are in fact only half-measures. Even the love of your neighbour, the fundamental virtue of Christian religion, proves ineffectual. Love of neighbour, like charity, is fulfilled in individual relationships, but is not sufficient to solve social issues ${ }^{1}$. Only in the Epoch of the Paraclete, due to social reforms, providing each person in need with daily bread will this be possible.

Cieszkowski believed that these reforms should embrace, among others, changes in the work organization and establishing the minimum required to live. Apart from material goods such as food and fuel, the notion of the social minimum contains also free of charge elementary education, dissemination of knowledge by means of latest technologies, establishment of public libraries, education of the working class, construction of free of charge baths and gyms, access to culture (entertainment). The social minimum is precisely this daily bread and denotes providing man with means at such a level that he will no longer need to work to live, but will live to work and develop. The notion daily bread, as Cieszkowski stresses, does not refer to luxuries, excess, abundance of goods, but to what is necessary and essential so that man might attain his innate goals and fulfil his destiny on earth. The lack of daily bread is not only the source of economic misery, but also of the most abhorrent crimes and transgressions. The author of Our Father drew the idea of the social minimum from Saint-Simon and Fourier, but the assertion that this social minimum is our daily bread is his own.

The fourth request is then of a material nature. This does not mean, however, that Cieszkowski rejects its metaphorical explanation. Thoughts are translations of Beings and so bread can be also perceived spiritually, but the interpretation cannot end here. The Christian Era gifted humanity with spiritual bread, but this epoch was unable to provide humankind with the financial means necessary to live (material bread). The problem is that in the present epoch the majority of social classes have neither material nor spiritual bread. In the new epoch this interpretation of the fourth request must be strengthened and based, in Cieszkowski's view, on three instruments: universal insurance (ensuring each man his hitherto wealth, protection against its loss), universal guarantee (ensuring the minimum of what man should possess and protection against poverty), universal association (ensuring access to what man may possess,

\footnotetext{
${ }^{1}$ See A. Cieszkowski, Ojcze-Nasz, vol. 3, p. 204.
} 
allowing man to attain whatever he has rights to and is skilled in both in material (industrial), and spiritual dimensions) ${ }^{1}$. This is precisely the daily bread that the praying man asks God for.

\section{Fifth petition}

The meaning of the fifth petition, And forgive us our trespasses, as we forgive them that trespass against us, can be only grasped when we realize that it contains two elements: request and declaration, future and present. Cieszkowski's analysis of this petition aims at determining the nature of the relationship between its constitutive elements (request and declaration). Declaration (we forgive them that trespass against us) refers to the present (the Christian Era) and contains the most important principle of a Christian attitude to other people. Request (forgive us our trespasses), in Cieszkowski's interpretation, touches upon two issues: the relationship of God to Humanity and the relationship of Humanity to God. In the Ancient epoch blind fate was the highest God. In Judaism God was presented as a Lord - He was the God of violence and vengeance. In Christianity God transforms from the Lord to the Father $-\mathrm{He}$ becomes God of the weak, the poor and the oppressed; He changes from the God of the vengeance to the God of grace and mercy: Fate (fatum) changed into Providence (providentia), Vengeance into Mercy, Justice into Grace. ${ }^{2}$ Providence, perceived as the influence of God on the world and Humanity, is an antithesis. Fate, just as Grace and Mercy, is only an antithesis of strict Justice. Standpoints presented by Antiquity and Christianity, being one-sided, require, in line with the principles of dialectics, synthesis: the union of vengeance and mercy as well as of justice and grace. Mercy and grace will be revealed in being forgiven our trespasses. Absolute Mercy and absolute Justice are one-sided. Only when justice becomes multiplied by grace, the unity (synthesis) of these contradictory standpoints will be attained. Cieszkowski unites principles that have hitherto been contradictory. This synthesis will characterize the future epoch. Similar oppositions can be found in the relationship of people to God. These concern oppositions that revealed themselves in rites. In the Ancient Era rites involved mainly mechanical (external) activities (making offerings); in Christianity, dominated by abstract spirituality, rites were manifested as repentance and penitence that were to erase the sin conceived within the spirit. Both forms of rites were one-sided. Consistently and in accordance with the dialectical method assumed by Cieszkowski, Christian one-sidedness must be abolished. This abolition must mean neither a complete rejection of the internal form of rites, nor the approximation to the standpoint characteristic for the Ancient Era. Instead, it must involve recognition that repentance, being the highest manifestation of Christian atonement, is not sufficient to free mankind from sin. Repentance is only justified in subjectivity (internal spirituality) and disregards externality. If in the future epoch deed and action are to be fulfilled,

\footnotetext{
${ }^{1}$ A. Cieszkowski, Ojcze-Nasz, vol. 3, pp. 216-217.

${ }^{2}$ A. Cieszkowski, Ojcze-Nasz, vol. 3, p. 224.
} 
internal repentance becomes, according to Cieszkowski, an inadequate notion ${ }^{1}$. Repentance as an internal and subjective act remains a necessary condition for atonement, but does not ultimately release man from guilt. Dialectically disjunctive notions of objective Offering (Antiquity) and subjective Atonement (Christianity) will become united in Action and through Action in the future epoch. Absolute and public mutual forgiveness of trespasses will occur. This act is a necessary condition for man to become worthy of being forgiven by God. Our destiny depends on our deeds, but we must also invoke God to collaborate because without God's Mercy the attainment of the ultimate goal, i.e. absolute sanctification, will not be possible. The fifth petition of the Lord's Prayer is then of a double nature: it fills us with pride and humility, Cieszkowski concludes.

\section{Sixth petition}

The sixth petition, And lead us not into temptation, unlike the previous ones is a negative one (staving off evil still contained in the Christian Era). The socalled positive requests (the first five petitions) aim at complementing negative evil that achieved full maturity neither in the Ancient Era nor in Christianity and will be fulfilled only in the third epoch. In the case of the previous petitions Cieszkowski explained why they could not be fully realized in Christianity and argued for the necessity of their fulfilment in the third epoch. He moved from one-sided standpoints to their synthesis, thus abolishing their limitations. In the case of the sixth petition his train of thought runs in an opposite direction. $\mathrm{He}$ negates one-sidedness to attain synthesis which is an absolute negation and not an absolute affirmation that he derived from the previous, positive requests. The third epoch is not concerned with victory of Adam or Christ, but with the abolition of temptation itself. In pre-Christian times human drives and passions were suppressed by coercion (external violence). In the Christian Era they were curbed by internal convictions and abnegations. In the epoch of Paraclet they will be equated with duties. Temptations, so far controlled due social reform, will be liberated. Cieszkowski does not mean here their apotheosis or approval of radical hedonism, but is concerned with imposing a normal direction on passions and drives and releasing them from shackles. They must be liberated because only then may they be applied to the accomplishments of political economy which proved that all limitations bring more harm than good. Instead of conflict, the principle of free trade should be introduced so that, rather than losses, harmony and benefits will be brought to all. A similar harmony should also exist in the sphere of the psyche. Economic liberty without additional social institutions would be, however, pernicious for mankind. The same holds true for the psyche that cannot develop its constituent parts without social instruments ${ }^{2}$. Cieszkowski connects the sixth petition of the Lord's Prayer with the third one. The object of the third petition (Thy will be done in earth, as it is in heaven) was the synthesis of subjective drives with will and objective law;

\footnotetext{
${ }^{1}$ A. Cieszkowski, Ojcze-Nasz, vol. 3, p. 228.

${ }^{2}$ A. Cieszkowski, Ojcze-Nasz, vol. 3, p. 252.
} 
the object of the sixth petition is to harmonize subjective drives and all constituent parts of the human spirit with each other ${ }^{1}$. When all objective antagonisms are abolished and Humanity enters the Third Era, individual fights will also lose their foundation. On the other hand, social institutions will support a quicker attainment of the internal standpoint compatible with external harmony.

\section{Seventh petition}

The seventh and last petition, But deliver us from evil, is also a negative request in Cieszkowski's terminology. It accumulates negative wishes and complements positive ones since the notion of Evil contains both a negative and positive evil that will be fulfilled only when the social reform takes place in the third epoch. The fulfilment of this petition is conditioned by the previous one since without abolishing temptation, deliverance from evil is impossible. The notion of Evil can be only grasped as a negation. Cieszkowski, referring to the well-known idea of Saint Augustine, claims that Evil is a privation, lack and negation of Good. Evil does not possess its own existence, it is not a real being (real substance). It is pure nothingness and relativity. Evil may be, but should not be; it is a possibility and not a necessity ${ }^{2}$. Cieszkowski points here to nature and its evil with which man constantly fights. Before man separated himself from nature, he had not experienced this evil. The state of not experiencing evil was, however, worse than its experiencing since, in Cieszkowski's understanding, it was a lower state. Man experienced evil when he got to know it; when his consciousness allowed him to separate himself from nature. Once he left the state of nature, man began to battle with it but cannot announce victory because he has not yet united the forces of nature with his own goals. If man unites himself organically with nature, evil, with its source in the fight, will disappear. Original sin (immanent evil) is a prototype of evil in the religious sphere. Man's initial fall was both physical and moral and so humanity must become reintegrated in both spheres. Without such reintegration the attainment of a harmonious unity will not be possible. The destiny of history and of mankind is the release from original sin. The Revelation of Christ brought about a moral renewal. Baptism freed man from original sin; it gave human subjectivity its due rights and consequently conditioned future salvation on human spirituality and will. Christ abolished subjective evil, but did not solve the problem of objective (physical) evil since without the negation of the physical sphere the elevation of the spirit would not be possible. Physical evil then still exists. We notice it in numerous contradictions embracing all spheres of material life (material world). It is necessary to reinstate nature with its rights, to sanctify the body, to reintegrate the entire physical sphere, to introduce a great social reform. This process of total physical reintegration is visible in the development of industry, inventions, art, which will be complemented in the third epoch (the synthetic one) in order to combat one-sidedness through the development of scientific knowledge. By negating the physicality of the ancient world, Chris-

\footnotetext{
${ }^{1}$ A. Cieszkowski, Ojcze-Nasz, vol. 3, p. 252.

${ }^{2}$ A. Cieszkowski, Ojcze-Nasz, vol. 3, pp. 263-264.
} 
tianity had to (dialectical necessity) contain evil in itself. What follows from the laws of dialectics is that Christianity could not have been the final Revelation. This assertion, Cieszkowski stresses, does not disparage Christianity in any way. The standpoint represented by Christianity turned out to be unsatisfactory, and so relatively and conditionally evil ${ }^{1}$. The recognition of this internal contradiction suggests that the time has come to move to the higher level. In the last petition Christ asks for the ultimate abolition of evil (complete release from original sin), for the harmony between matter and spirit, for a harmonious union of all contradictions existing in the world that we have become conscious of ${ }^{2}$.

\section{The Kingdom of God on earth}

What must change in the hitherto order of the world so that the third Revelation can be fulfilled? What will the promised Kingdom on earth be like? Cieszkowski provides his answers to these questions in two chapters of volume two of Our Father: The Philosophico-Historical Genealogy of the Kingdom of God and The Reconciliation of Religion and Politics. A social state is the destiny and the underlying condition of human life. Man cannot exist without others since in others he is fulfilled as man. It is society which makes man who he is. Thus society is the same for man as nature is for animals. Nature is not sufficient for man. Man, as an uncompleted being which is perfecting itself, had to abolish the state of nature. Leaving the state of nature by man marks the beginning of society. Society, just as man in his individual life, passes through periods of childhood, youth and maturity. The state of childhood of humankind was chiefly physical. Society developed under natural conditions. The human spirit sought after self-knowledge and tried to win its way out of relations imposed by nature. This was the time of the natural development of the human spirit (the state of childhood) which lasted throughout the Ancient Age. In the second period (youth) the human spirit discovered the ideal constituent part and turned towards it. It rejected what was given to it (given conditions), began to develop what it had won out of its inner self and to form new society accordingly. The period of youth was an abolition and negation of the first (the state of nature) and lasted throughout the Christian Era. In terms of social relations, Christendom was a negation of the relations characteristic of the Ancient Era, a transition from a real Republic to an ideal Republic. Christ made the principle of society alive by postulating love and universal brotherhood. This command was, however, of a subjective nature since it concerned the inner life of individuals. Being born again in spirit was then necessary in order to negate and reject the external world. Without it, a Christian would not have been able to approximate the Kingdom of God. Christ's postulate was, however, only a moral command for individuals but not a social one for all. In this sense an ideal Republic was the Kingdom of God in potentia, a postulate, an assumption. In order to fulfil it in Action and not only in Word, the internal rebirth of man is insufficient. The outward New Birth, that is the New Birth of societies

\footnotetext{
${ }^{1}$ A. Cieszkowski, Ojcze-Nasz, vol. 3, p. 280.

${ }^{2}$ A. Cieszkowski, Ojcze-Nasz, vol. 3, p. 280.
} 
themselves, must occur instead ${ }^{1}$. This will happen in the third epoch (the Age of Action, the Age of the Paraclete). Ideal (abstract) and individual principles of Christianity, hitherto contained inside man as the Word, must be fulfilled in social institutions. In terms of society, the age of the Paraclete is a transition from the Militant Church to the Church Triumphant. - Thus the Kingdom of God on earth is related to the Kingdom of Christianity, that was not yet of this world, as Action to Knowledge, Reality to Idea, Fulfilment to Possibility. ${ }^{2}$ The Kingdom of God on earth is to be the Church of Humanity. Yet this has nothing to do with the cosmopolitan idea of uniformity and the abolition of national distinctness. Quite the opposite, the Church of Humanity will acknowledge the autonomy of nations and an organic society will be formed out of them. Just as individuals create a people, in the same way societies will unite to form Humanity. Hitherto Humanity existed only in ideas, in the field of thought. Now is the time for Humanity to become reality and the time for societies moving to the stage of a Society of societies. This is the promised Kingdom of God on earth. Thus far each individual's motherland was his own homeland which he served according to his skills and possibilities. Now all nations will serve, complementing each other, one common Motherland of Humanity. However, service does not mean that one nation will be subservient to another. It means equality. Motherland of Humanity will be constituted of free nations, according to their abilities and destinies. The Kingdom of God cannot be fulfilled only in one place and only for one nation, but embraces all places and all nations. There are no chosen or better nations. All nations are equal since each has in some way contributed to the approximation of the Kingdom of God. Peaceful coexistence is the foundation of the future Union of the Nations, but Humanity will not attain the state of organic coexistence as long as ultima ratio rerum are [...] the bayonet and the big gun ${ }^{3}$. The condition of the Kingdom of God is the uniting of Humanity in an age-long and universal peace.

Cieszkowski believed that the previous projects of everlasting peace authored by Henry of Navarre, Leibniz, Bernardin de St. Pierre, Rousseau, Kant, Fichte, Bentham had been fancies and utopias. Some believed that the way towards peaceful coexistence is to unite all European nations by violence or less drastic measures under one rule and according to one political program. Others dreamt about an artificial, cosmopolitan covenant. No one, however, has yet thought that nations themselves must transform into a higher whole, be born again and be bound by religion. Politics must be born again: it must undergo a religious revival and from being heathen become Christian. The future alliance of nations must be bound by religion. The ideal of everlasting peace will not be made into a reality as long as the nations are not united in religion, are not born again in the spirit, are not united in the Society of the Holy Spirit ${ }^{4}$. In heathen times religion served nations; in the Christian Era nations began to serve

\footnotetext{
${ }^{1}$ A. Cieszkowski, Ojcze-Nasz, vol. 2, p. 57.

${ }^{2}$ A. Cieszkowski, Ojcze-Nasz, vol. 2, p. 59.

${ }^{3}$ A. Cieszkowski, Ojcze-Nasz, vol. 2, p. 65.

${ }^{4}$ A. Cieszkowski, Ojcze-Nasz, vol. 2, p. 70.
} 
religion. Despite conflicts and political diversity, it is religion that has remained the force capable of retaining unity. Only religion, social in its very nature, is capable of leading the world to the ideal Communion. By acknowledging God as the Holy Spirit, society is elevated to the Society of the Holy Spirit. Those who believe that humanity no longer needs religion do not know, according to Cieszkowski, its essence. They perceive it as mere catechism or symbolic ceremony, but in fact religion is absolute harmony. If we remove this uniting force of religion, we will cease to exist as a society. Without religion people would have no common aims and goals. Just as man cannot exist without society, society cannot exist without religion since without religion it would no longer be society. Society without religion is both an absurd and nonsense. Those who declare that they do not need religion negate the very existence of society since society is Religion ${ }^{1}$. The conception of religion as the absolute bond of the universe aims at the highest good of the Spirit which requires both material and ideal satisfaction since the Spirit is the unity of the soul and the body. Cieszkowski contained the ideal of the Kingdom of God on earth in the postulates embracing both spheres of the Spirit. The first one proclaims the necessity to develop all the gifts of the spirit and all constituent parts of Humanity in order to elevate them to a higher level. The second concerns the conscious realization of the Freedom of the Spirit. It is to be fulfilled in the unity of the common order and of the religious rite and the conception of the Government as the centre of human life. The third postulate discusses the necessity of such a construction of this Government that all who are capable of activity be its members and actually take part. The principle of self-government should prevail at each level of social life. The fourth postulate confirms the importance of participation and co-operation in all spheres of life. This is, according to Cieszkowski, the social duty and, at the same time, a religious one. The duty to participate in the Government is an act of religious observance and a condition for future salvation. Participation in the Government, where God is King, is service of God.

The recognition of public service (Service of Humanity) as service of God is contained in the next postulate: public service is the destiny and social consecration of man. Other postulates stress that the higher the office one holds and the more one serves, the more servus servorum they are, the more social duties and greater merits they have. The greatest merit is the merit before God and for God. Whoever does not work for their communities, nations, churches, and does not actively participate in this universal Kingdom, is a burden. Universal social consecration is neither an abstract consecration for its own sake, nor useless self-mortification and ascetic worrying, but a useful consecration. It rounds out and hallows life. It is a Divine and earthly institution, both State and Church, an organic wholeness ${ }^{2}$.

The Dominion of God on earth constitutes the idea of uniting worldly affairs with eternal ones. In this idea, the goal of life and the means of salvation

\footnotetext{
${ }^{1}$ A. Cieszkowski, Ojcze-Nasz, vol. 2, p. 84.

${ }^{2}$ A. Cieszkowski, Ojcze-Nasz, vol. 2, pp. 86-88.
} 
are transferred from the Heaven of Faith to the Earth of Life, and the endeavours of earth are raised to the dignity of religious duties (towards God). Cieszkowski hallows social action and recognizes it as Virtue itself. The command of fulfilment in action concerns all professions and callings, be it the most subordinate or the highest ones. The necessary condition is to use all abilities and willingness to act. To neglect action means to commit sin against the active Spirit. The foundation of social harmony is co-operation in public affairs of all members of society, according to one's position, abilities and merits ${ }^{1}$. The lack of this co-operation leads to fights and conflicts and results in social disharmony. Social harmony can only be attained by the conscious creation and development of public institutions (social life) through Action. The individual participation in the matters of one's community (nation), and co-operation of particular nations regarding the universal Humanity are subjective conditions for the existence of the Kingdom of God. These subjective conditions (individual workings of citizens and nations) are supplemented with objective conditions: organization, government and order. Just as liberty, Order is a condition for the existence of self-government and its organ is government: a strong, efficient and central administration that co-operates with autonomous local municipalities. The principle of government and of Office is free election. The social authority comes from God through the People, and from the People through God.

The Catholic Church, under the guise of defending its unity, combated diversity. The Catholic hierarchy of the Kingdom of God cannot make such an error; it can neither exclude any form of government, nor diminish municipal autonomy. It has to be based on the principle of political and religious tolerance. This means the acceptance of diversity. Particular units of society are to contribute together, each as its abilities permit, to the life and development of the whole. Apart from self-government and voluntary self-constitution, governments must co-operate with universal organizations, i.e. a Universal Government (the highest executive authority), a Universal Parliament (the highest legislative authority) and a Universal Areopagus (Tribunal) of the Nations (the highest judicative and controlling authority). Due to these organs Humanity is no longer a phantasm (an abstract notion). It has its own universal Parliament, universal Government and universal Areopagus of the Nations. The task set forth for these institutions is to move Humanity from a state of idea (abstraction) to one of reality (activity) ${ }^{2}$. The third, subjective-objective, condition of the Kingdom of God is the existence and ruling of the Social Spirit (a living Public-spiritidness). Without this Spirit all institutions are dead and subjective impulses inimical. The Social Spirit revealing itself in civic virtue is the basis for true democracy, a condition of elective government and republican institutions. The fullness of the Social Spirit could not come because the revelation of the Holy Spirit had not been yet fulfilled. The mark of the Public Spirit is a right and common action in all the relations of life with the neglect

\footnotetext{
${ }^{1}$ A. Cieszkowski, Ojcze-Nasz, vol. 2, p. 94.

${ }^{2}$ A. Cieszkowski, Ojcze-Nasz, vol. 2, pp. 104-105.
} 
of law ${ }^{1}$. Cieszkowski understands this as the substitution of living habit for dead law (legislation), in other words by law which is not external compulsion, but is in the hearts of its citizens. Public law is only living when it has grown out of the national spirit. When public action is recognized as virtue, public service as the only merit, and the right to this service as religious duty, and political duty as a religious right then the lordship of the Holy Spirit in His Community will begin. In order for this state to be fulfilled, violence and coercion must be eliminated from political life (penal law and the hangman cannot be the only Masters of Justice); secular institutions must become sacred. Cieszkowski rejects the hitherto social and political theories with their dead legality and artificial legitimation as useless for the salvation of the world. He admits that they contained a particle of truth, but were goals themselves whereas they should be the means toward the goal that is Society of the Spirit. Principles, laws, institutions and rites of the old Church should be fitted to human life and thus become the principles of the universal Church of Humanity. The future Kingdom of God cannot be established forever as one and unchanging. It must contain conflict, as in the old Church. Conflict does not exclude harmony; quite the opposite. Harmony without conflict is, according to Cieszkowski, a fancy ${ }^{2}$.

\section{Conclusion}

The prayer Our Father is addressed to Christians. Petitions contained in it can be perceived as the awaiting for the birth of the new society in which all shortages of the Christian Era will be supplemented. In the future epoch humanity will cease to treat God as a being not of this world, but as a cooperating being, living with humanity. The earthly life of Christ was a mystical prophecy of what will happen in a future society through the lordship of the Holy Spirit. The Messiah will return in the third person of the Trinity sent to the whole Humanity. The unity of the faith announced by Christ will be fulfilled in the future society and the Kingdom of God on earth will be become real. It will embrace a new social, legal and moral state of social life. This new order will be implemented without the use of force, without violence, but through the reconciliation of natural desires and duties. Nothing will limit the development of the most important goals of mankind (family, society, state), and Beauty, Truth and Good will finally be fulfilled in art, science and religion. The coming Kingdom of God will abolish the contradiction between the will of God and the earthly will of individuals. All social strata will be equal and this equality will not be abstract but real. Belief in Divine justice and mercy will be strengthened by the conviction that our happiness depends on us. Humanity will be freed from all evil. We should say the Lord's Prayer until all petitions contained in it are fulfilled. When this is done, we may abandon saying these requests. In the fulfilled Kingdom of God on earth the Lord's Prayer will be a remnant and monument of the Divinity of Jesus Christ ${ }^{3}$.

\footnotetext{
${ }^{1}$ A. Cieszkowski, Ojcze-Nasz, vol. 2, p. 110.

${ }^{2}$ A. Cieszkowski, Ojcze-Nasz, vol. 2, p. 119.

${ }^{3}$ A. Cieszkowski, Ojcze-Nasz, vol. 3, p. 286.
} 
Cieszkowski's Our Father was a reference point for, inter alia, Polish Neomessianists at the turn of the $19^{\text {th }}$ and $20^{\text {th }}$ centuries, who employed certain ideas presented in this work to build their own messianic theories. Our Father has been frequently interpreted in Poland and the sheer number of these interpretations indicates that this work eschews a univocal assessment since it is both of a religious and philosophical nature, and also contains ample social, economic and political comments. In the religious dimension, this work is of a prophetic character, but at the same time it offers a realistic program of social and economic reforms. The most numerous group of its interpreters consists of historians of philosophy and historians of ideas who interpret Cieszkowski's work as an ideology. A. Roszkowski terms it a social ideology inspired by French utopian socialism. He believes that French utopian socialists' ideas most heavily influenced Cieszkowski's treatise and outweighed the influences of German idealism and Protestant theology. Roszkowski simultaneously emphasizes the practical dimension of Our Father, and, taking into account this aspect, he terms Cieszkowski's standpoint a liberal solidarism, similar to modern types of cooperativism ${ }^{1}$. The impact of French thinkers on Our Father is also stressed by an outstanding Polish historian of ideas, an expert in Polish Romanticism, A. Walicki. In his view, Cieszkowski's work contains motifs unique for the philosophical and religious as well as social and religious French thinkers such as Saint-Simon and Fourier, Ballanche, Saint-Simonists, Leroux, Reynaud, Boucher de Perthes. These include, for instance, the idea of social Palingenesis, criticism of Christian duality, conception of a new religion that rehabilitates matter and the earthly dimension of human life, the idea of religious progress and new revelation ${ }^{2}$. Walicki also notices the correspondences between Cieszkowski's ideas and German philosophy contemporary to him. The ideological character of Our Father is, however, mostly due to relations with French utopian socialism based on millenarianism, that is a religious, yet secularized, thought proclaiming the creation of the Kingdom of God on earth. According to S. Janeczek, Walicki, while retaining the thesis of the secularization of Cieszkowski's ideas, places stress on different issues, attenuating heterodoxy of his millenarianism, since he comes to appreciate ever more the permanence of the historical dimension of Christianity and also highlights the Polish and moralistic roots of Cieszkowski's messianism grounded on Christianity ${ }^{3}$. In Janeczek's opinion, Walicki's interpretation is dominated by the point of view presented by the so-called Warsaw school of historians of ideas that analyzes philosophy in line with the sociology of knowledge, perceiving it as a manifestation or element of ideology. For this reason, he believes the social message of Cieszkowski's work to be mostly a manifestation of a utopian ideology ${ }^{4}$. Our Father is also interpreted ideologically (collective worldview) by S. Pieróg, who notices also its practical dimension enabling the

\footnotetext{
${ }^{1}$ See A. Roszkowski, Poglądy spoleczne i ekonomiczne Augusta Cieszkowskiego, pp. 160-162.

${ }^{2}$ A. Walicki, Polska myśl filozoficzna epoki międzypowstaniowej, p. 33.

${ }^{3}$ S. Janeczek, Ojcze nasz Augusta Cieszkowskiego ..., p. 14.

${ }^{4}$ S. Janeczek, Ojcze nasz Augusta Cieszkowskiego ..., p. 16.
} 
undertaking of collective actions in line with historiosophies formulated for these actions ${ }^{1}$. An ideological perspective also characterizes the interpretation of Our Father presented by M. N. Jakubowski. In his view, Cieszkowski wished to reconcile a religious revelation with historicism, hence he assumed that Christianity in its present form must end, together with the Catholic Church. It will be abolished in a Hegelian way, its structure, doctrine and rite will change ${ }^{2}$. In Jakubowski's interpretation, Cieszkowski secularizes the understanding of religion since man's duty in the future epoch will be free (since based on the knowledge of necessary laws) work in the sphere of science, art and political and economic life ${ }^{3}$. On the other hand, P. Bartula labels Cieszkowski's ideas Christian liberalism. Conservative liberalism revealed itself in his thesis mostly as religious respect for the historical evolution of the global society, and respect for unique national traditions ${ }^{4}$. In the future democratic system established laws would be limited by customary laws and would be permeated with metaphysical laws of the Absolute being fulfilled in the history of Christianity. Bartula also indicates that the terrestalization of eschatology did not serve Cieszkowski to

condemn the material dimension of human life, but, quite the opposite, meant the elevation of economy, and even the sacralization of mass production. This allowed him to expose the illusory nature of the Romantic notion of the contradiction between the goals of the economy of Revelation and intra-world economy. A far-reaching inter-dependence, and sometimes identity, can be found between these two schemes of goals. ${ }^{6}$

A. Wawrzynowicz notices that in Our Father Cieszkowski breaks with Hegel and with a philosophical perspective; he subordinates Hegelian method to the perspective of religious philosophy. Cieszkowski intended to reconcile philosophical and religious discourse. In Our Father he performs this reconciliation within an intellectual paradigm of the philosophy of revelation ${ }^{7}$. W. Sajdek interprets Our Father as both a philosophical and religious treatise. In her interpretation, Cieszkowski continues Hegel's thought, but enriches it with the vision of a new, future epoch that he designs based on the ideas of French utopian socialism, Christianity and science, economy in particular ${ }^{8}$. Heterodoxy of Our Father constitutes a separate issue. Polish religious thinkers of an older

\footnotetext{
${ }^{1}$ See S. Pieróg, Modlitwa jako ideologia, p. 118.

${ }^{2}$ M. N. Jakubowski, Czyn, przyszłość, naród. Poglądy filozoficzne Augusta Cieszkowskiego, p. 66

${ }^{3}$ M. N. Jakubowski, Czyn, przyszlość, naród. Poglądy filozoficzne Augusta Cieszkowskiego, p. 57.

${ }^{4}$ P. Bartula, Chrześcijański liberalizm Augusta Cieszkowskiego, p. 180.

${ }^{5}$ P. Bartula, Chrześcijański liberalizm Augusta Cieszkowskiego, p. 181.

${ }^{6}$ P. Bartula, Chrześcijański liberalizm Augusta Cieszkowskiego, p. 181.

${ }^{7}$ A. Wawrzynowicz, Geneza powstania Ojcze nasz Augusta Cieszkowskiego - fakty i mity, pp. 119-120.

${ }^{8}$ W. Sajdek, Polski Sokrates. Pojęcie czynu w filozofii Augusta Cieszkowskiego, pp. 7-10.
} 
generation, e.g. E. Ziemięcka, F. Gabryl, and after World War II, inter alia, M. Klepacz, expressed their reservations as to Cieszkowski's ideas and accused him of heterodoxy. In his work devoted to Polish interpretations of Our Father, S. Janeczek observes that these accusations were formulated mostly from the perspective of the pre-Second Council theological rigor that stressed the dangers of rationalism as endangering faith [...]. This issue looks differently in the perspective of Vaticanum II. Modern theology is pluralist, retains a relative freedom of speech in science, which cannot be equated with the narrower doctrine of the magisterium of the Catholic Church (Magisterium Ecclesiae), since the unity of theology in the multiplicity of methods and disciplines is postulated directly. ${ }^{1}$

According to S. Janeczek, Our Father may be treated both as a manifestation of religious philosophy and Catholic social science. Difficulties as to how to qualify particular statements made by Cieszkowski, understood in a theological perspective, do not warrant doubting the honesty of his intentions as well as their realization not only on the grounds of Christianity, but also Catholicism ${ }^{2}$. He also suggests abandoning the term ideology with respect to ideas contained in Our Father. Cieszkowski, as Janeczek rightly indicates, could not know the negative connotation attributed to it by K. Popper. He suggests the nonjudgmental term intellectual mindset as the substitution for ideology $y^{3}$.

In my opinion, Our Father should be examined synthetically, taking into account that the argument employed by Cieszkowski belongs neither only to the sphere of religion, nor philosophy, nor social thought (economy). These lines of argumentation should not be separated since they are organically united in Cieszkowski's work. The emphasis placed only on one type of idea and ascribing to it the significance of the leading idea, thus subscribing Our Father to a specific standpoint, diminishes the importance of others. This also means that it is difficult to find one collective term that would embrace all ideas presented in this work. I share S. Janeczek's opinion that the ideologization of religion in Cieszkowski's oeuvre should be rejected. This problem should be considered in a broader perspective accounting for the changes that occurred in the Polish philosophy of that time. In the first phase of the development of Polish Romantic philosophy, its main task was to defend religion against the Enlightened reason. This concerned the defence of religion in line with orthodoxy. In the 1840s (the second phase of the development of Polish Romantic philosophy) outstanding representatives of Polish national philosophy (Cieszkowski, B. F. Trentowski, K. Libelt) desired to unite philosophy with religion ${ }^{4}$. This was another form of defence of religion, but this religion was

\footnotetext{
${ }^{1}$ S. Janeczek, Ojcze nasz Augusta Cieszkowskiego ..., p. 34.

${ }^{2}$ S. Janeczek, Ojcze nasz Augusta Cieszkowskiego ..., p. 46.

${ }^{3}$ S. Janeczek, Ojcze nasz Augusta Cieszkowskiego ..., p. 47.

${ }^{4}$ E. Starzyńska-Kościuszko, Opozycja, synteza czy „,trzecia droga”, pp. 111-139.
} 
reconciled with philosophy. In the case of Our Father, its philosophical dimension is not limited to the application of the dialectical method, but also includes the social and economic program contained in it. Providing religion with philosophical attributes was not meant to secularize religious beliefs. Our Father attempts to find a common ground to present religion and philosophy not as opposite ideas, but ideas that can be reconciled within one coherent vision of the future.

This paper has been conceived not only from the conviction that it is necessary to popularize the most outstanding achievements of Polish thought, but also because Our Father contains ideas that can still prove valid, even if readers are put off by the archaic language of this work, the term messianism and the vision of a world based on religious foundations. These valid points include: the idea of making politics ethical, the union of the universal with the particular (Cieszkowski designed his visions of the future not only thinking of the Polish nation deprived of its sovereign entity then, but also referring to the entire world) and its practical dimension, indicating that theories should be implemented in life and realized in the form of social projects that can change the existing reality.

\section{Bibliography}

Bartula P., Chrześcijański liberalizm Augusta Cieszkowskiego in: Filozofia a religia $w$ dziejach filozofii polskiej, (eds.) S. Janeczek \& A. Starościc, KUL, Lublin 2014, pp. 177-191.

Cieszkowski A., Ojcze-Nasz, vol. 1-2, J. Czernecki, Poznań 1922.

Cieszkowski A., Ojcze-Nasz, vol. 3, J. Czernecki, Poznań 1922.

Cieszkowski A., Prolegomena zur Historiosophie, Gebr. Unger, Berlin 1838.

Cieszkowski A., Prolegomena do historyozofii, J. Fr. Tomaszewski, Poz- nań 1908.

Jakubowski M. N., Czyn, przyszłość, naród. Poglady filozoficzne Augusta Cieszkowskiego, PWN, Warszawa \& Poznań 1989.

Jakubowski M. N., Ciagłość historii i historia ciagłości. Polska filozofia dziejów, UMK, Torun 2004.

Janeczek S., Ojcze nasz Augusta Cieszkowskiego - ideologia, filozofia religijna, katolicka nauka społeczna? Przeglad stanowisk in: Romantyzmy polskie, (eds.) A. Dziedzic, T. Herbich, S. Pieróg \& P. Ziemski, Fundacja Historii Filozofii Polskiej, Warszawa 2016, pp. 7-49.

Pieróg S., Modlitwa jako ideologia. Próba interpretacji Ojcze nasz Augusta Cieszkowskiego in: August Cieszkowski. W setna rocznice śmierci, Wydawnictwo Polskiego Towarzystwa Filozoficznego, Warszawa 1966, pp. 108-125.

Roszkowski A., Poglady społeczne i ekonomiczne Augusta Cieszkowskiego, Fiszer i Majewski, Poznań 1923.

Sajdek W., Polski Sokrates. Pojęcie czynu w filozofii Augusta Cieszkowskiego, KUL, Lublin 2013.

Starzyńska-Kościuszko E., Opozycja, synteza czy ,trzecia droga”? Filozofia $i$ religia $w$ pogladach przedstawicieli polskiej ,filozofii narodowej” lat 
czterdziestych XIX wieku in: Filozofia a religia $w$ dziejach polskiej filozofii. Inspiracje-krytyka, (eds.) S. Janeczek \& A. Starościc, KUL, Lublin 2014, pp. 111-139.

Walicki A., Polska myśl filozoficzna epoki międzypowstaniowej in: Filozofia $i$ myśl społeczna w latach 1831-1864, A. Walicki, A. Sikora \& J. Garewicz, PWN, Warszawa 1977, pp. 111-125.

Wawrzynowicz A., Geneza powstania Ojcze nasz Augusta Cieszkowskiego fakty $i$ mity in: Światopogladowe odniesienia filozofii polskiej, (eds.) S. Janeczek, R. Charzyński \& M. Maciołek, KUL, Lublin 2011, pp. 119-120. 